\title{
Article 30. Procedures and Mechanisms to Promote Compliance with this Protocol
}

The Conference of the Parties serving as the meeting of the Parties to this Protocol shall, at its first meeting, consider and approve cooperative procedures and institutional mechanisms to promote compliance with the provisions of this Protocol and to address cases of non-compliance. These procedures and mechanisms shall include provisions to offer advice or assistance, where appropriate. They shall be separate from, and without prejudice to, the dispute settlement procedures and mechanisms under Article 27 of the Convention.

\section{Overview}

Article $30^{1}$ is an enabling provision, ${ }^{2}$ which mandates the establishment of multilateral procedures and mechanisms for monitoring compliance and addressing instances of non-compliance with the Protocol. Similarly to the Biosafety Protocol, ${ }^{3}$ it provides a definite mandate to the Protocol's governing body ('consider and approve') and a time frame 4 ('at its first meeting'). ${ }^{5}$

Article 30 indicates that the aim of the compliance procedures and mechanisms will be two-fold: on the one hand, to promote compliance and, on the other hand, to address cases of non-compliance. It further provides some indication as to the nature of these procedures and mechanisms ('cooperative and non-adversarial') and the relevant powers, by pointing to the possibility to offer advice or assistance, and clearly distinguishing them from dispute settlement

1 This provision was first incorporated in the Cali Draft.

2 This is a common approach in other multilateral environmental agreements, such as the Kyoto Protocol, Article 18; the Stockholm Convention on Persistent Organic Pollutants (Stockholm, 22 May 2001, in force 17 May 2004) 2256 unts 119, Article 17; and ItPGRFA, Article 21. See also Greiber et al., Explanatory Guide, op. cit., 244.

3 Biosafety Protocol Article 34. See Mackenzie et al., Explanatory Guide to the Cartagena Protocol, op. cit., 193-196.

4 For similar considerations in the context of the Biosafety Protocol, see ibid., 194.

5 Which will be held concurrently with the first meeting of the СвD СоР that is to convene after the Protocol's entry into force: Protocol Article 26(6). See this commentary on Article 26. 
procedures. ${ }^{6}$ All other elements of the procedures and mechanisms, including their form, the full array of their powers, the determination of entities entitled to trigger consideration of cases of non-compliance and the nature of measures to address non-compliance will have to be defined in subsequent negotiations and eventually be adopted by the Protocol's governing body.

To a certain extent, the compliance procedures and mechanisms to be established under the Protocol will share features that have become commonplace across multilateral environmental agreements. ${ }^{7}$ On the other hand, some distinctive features of the Protocol will likely lead Parties to consider innovative approaches to multilateral compliance procedures and mechanisms. The following sections will therefore discuss some of the likely common features of compliance procedures under the Nagoya Protocol and other MEAs, and then focus on likely distinctive features. The relation of Article 30 with other compliance-related provisions of the Protocol, and with international dispute settlement mechanisms, will be analyzed next.

\section{Common Features}

Compliance procedures, including the creation of a compliance committee, have become a common feature of MEAs - although negotiations for their establishment have proven quite arduous. ${ }^{8}$ Compliance procedures represent a response to general and individual issues related to compliance with international treaties, that are based on problem-solving through negotiation with

6 The Nagoya Protocol does not contain a provision on dispute settlement, but СвD Article 27 on dispute settlement is applicable in this context (pursuant СвD Article 27(5), which reads: 'The provisions of this Article shall apply with respect to any protocol except as otherwise provided in the protocol concerned.')

7 See for example: Birnie, Boyle and Redgwell, International Law and the Environment, op. cit., 211-213 and 237-250; Ulrich Beyerlin, Peter-Tobias Stoll and Rüdiger Wolfrum, eds., Ensuring Compliance With Multilateral Environmental Agreements: A Dialogue Between Practitioners and Academia (Leiden: Martinus Nijhoff Publishers, 2006); Tullio Treves et al., eds., Non-Compliance Procedures and Mechanisms and the Effectiveness of International Environmental Agreements (The Hague: Asser Press, 2009); Ronald B. Mitchell, "Compliance Theory: Compliance, Effectiveness and Behaviour Change in International Environmental Law" in Bodansky, Brunnée and Hey, The Oxford Handbook of International Environmental Law, op. cit., 893; and André Nollkaemper, "Compliance Control in International Environmental Law: Traversing the Limits of the National Legal Order," Yearbook of International Environmental Law 13 (2003): 165.

8 For a comparative discussion, see Morgera et al., "Implementation Challenges," op. cit. 
a view to identifying a flexible and pragmatic multilateral solution to questions of interpretation of a treaty, as well as alleged breaches. ${ }^{9}$ The outcome of compliance procedures can be an authoritative determination of the correct interpretation of a treaty provision or a declaration of non-compliance by a certain Party. But it may also be (in addition or in alternative) a more pragmatic proposal to manage non-compliance problems in order to achieve an 'acceptable level of compliance' in the future, rather than establishing rights and duties under the treaty. ${ }^{10}$ In that connection, compliance mechanisms are more fundamentally geared towards promoting future compliance rather than punishing past non-compliance, with the ultimate aim of seeking to promote the effectiveness of the regime as a whole. ${ }^{11}$ To that end, the outcome of compliance procedures may not be necessarily dictated by international law, but rather accommodate the interests of all Parties, thereby facilitating multilateral solutions and restoring mutual trust. ${ }^{12}$ As a result, in different combinations, compliance mechanisms generally mix a 'managerial' and 'enforcement' approach, ${ }^{13}$ encouraging Parties to engage in better planning of actions needed for ensuring compliance. ${ }^{14}$ Sanctions and disincentives are usually reserved only to tackle recalcitrant Parties.

It should also be noted that compliance mechanisms provide an opportunity for the wider international community, beyond State Parties, to exercise multilateral pressure on non-compliant Parties. Thus, not only Parties but also observers, notably NGOS, ${ }^{15}$ can participate (in different ways and to different extents, depending on the specific procedures of the compliance mechanisms) $)^{16}$

9 Antonio Cardesa-Salzmann, "Constitutionalising Secondary Rules in Global Environmental Regimes: Non-Compliance Procedures and the Enforcement of Multilateral Environmental Agreements," Journal of Environmental Law 24 (2012): 103; see also Birnie, Boyle and Redgwell, International Law and the Environment, op. cit., 245-250.

10 Bodansky, Art and Craft of International Environmental Law, op. cit., 251.

11 Ibid., 232-233.

12 Ibid., 226 and 251.

13 For this terminology, see Abram Chayes and Antonia Handler Chayes, "On Compliance," International Organization 47 (1993): 175; and Jutta Brunnée, "Multilateral Environmental Agreements and the Compliance Continuum," in Winter, Multilevel Governance of Global Environmental Change, op. cit., 387.

14 Bodansky, Art and Craft of International Environmental Law, op. cit., 235.

15 Alessandro Fodella, "Structural and Institutional Aspects of Non-Compliance Mechanisms," in Treves et al., Non-Compliance Procedures, op. cit., 355; and Birnie, Boyle and Redgwell, International Law and the Environment, op. cit., 244.

16 Veit Koester and Tomme Young, "Compliance with International Conventions: The Role of Public Involvement," Environmental Policy and Law 37 (2007): 399. 
in negotiations for equitably balancing the interests of different Parties and for determining appropriate forms of assistance, taking into account experience and knowledge of different stakeholders involved in treaty implementation. It should be noted that compliance mechanisms have also raised concerns about the respect for the rule of law in MEAs. It has in fact been argued that compliance with international obligations becomes 'intensely negotiable,' which possibly leads to a 'relativization of international law's normativity' and conceals fundamental disagreement among relevant actors about the significance of international rules and their breach. ${ }^{17}$

The intergovernmental process preparing for the entry into force of the Protocol already engaged in the identification of useful elements of inspiration from other compliance mechanisms under other MEAs. ${ }^{18}$ Useful elements could include the possibility for a future compliance committee ${ }^{19}$ to take facilitative measures in its own capacity, ${ }^{20}$ to address non-compliance also through

17 Klabbers, “Compliance Procedures," op. cit., 995.

18 The СвD Secretariat initially drew attention to the compliance mechanisms of the Biosafety Protocol and of the ITPGRFA in CвD Secretariat, "Cooperative procedures and institutional mechanisms to promote compliance with the Protocol and to address cases of non-compliance" (6 September 2011) Un Doc UNEP/CBD/ICNP/1/6/Rev.1. But relevance of other experiences under other MEAs was later considered: ICNP, "Report of the Expert Meeting on Cooperative Procedures and Institutional Mechanisms to Promote Compliance with the Nagoya Protocol on Access and Benefit-Sharing and to Address Cases of Non-Compliance" (1 March 2012) Un Doc UNEP/CBD/ICNP/2/12, paragraphs 47 and 52 .

19 While a decision has still be to taken on whether a compliance 'committee' will be established under the Nagoya Protocol, negotiating documents at the time of writing clearly point in that direction: ICNP Recommendation 2/7 "Cooperative procedures and institutional mechanisms to promote compliance with the protocol and to address cases of non-compliance", Annex, paragraph B.1, in ICNP, 'Report of the second meeting," $\mathrm{UNEP} / \mathrm{CBD} / \mathrm{COP} / 11 / 6$, Annex.

20 ItPGRfa Article 21: "The Governing Body shall, at its first meeting, consider and approve cooperative and effective procedures and operational mechanisms to promote compliance with the provisions of this treaty and to address issues of non-compliance. These procedures and mechanisms shall include monitoring, and offering advice or assistance, including legal advice or legal assistance, when needed, in particular to developing countries and countries with economies in transition.' See ENB. "Summary of the Fourth Session of the Governing Body of the International Treaty on Plant Genetic Resources for Food and Agriculture: 14-18 March 2011," Vol. 9 No. 550, 21 March 2011; and Elsa Tsioumani, "ItPgrfa. Compliance Procedures and Operational Mechanisms," Environmental Policy and Law 41 (2011): 74. 
punitive measures, ${ }^{21}$ to seek information through the Secretariat, to conduct visits to the territory of the Party under investigation if invited to do so, ${ }^{22}$ and to consider reports of expert teams reviewing Parties' national reports. ${ }^{23}$ A notable potential source of inspiration would be the Convention on Access to Information, Public Participation in Decision-making and Access to Justice in Environmental Matters ('Aarhus Convention'), whose compliance mechanism can be triggered ${ }^{24}$ by stakeholders ${ }^{25}$ and includes NGOS as members of

21 This is the case of CITES, for instance, where powers were derived from a provision in CITES Article XI, enabling the cop to make recommendations to improve the effectiveness of the Convention, coupled with majority-voting decision making. Compare cites Resolution Conf. 14.3 "Cites Compliance Procedures," cites, accessed 30 November 2013, <www .cites.org/eng/res/all/14/E14-03C15.pdf>. See generally Rosalind Reeve, "Wildlife Trade, Sanctions and Compliance: Lessons from the cites Regime," International Affairs 82 (2006): 881. See also Kyoto Protocol Articles 3(1), 5(1), 5(2) and 7(1); and Decision 27/ CMP.1 "Procedures and mechanisms relating to compliance under the Kyoto Protocol" (30 March 2006) un Doc. FCCC/KP/CMP/2005/8/Add.3, Annex, section XV. See Jacob Werksman, "Compliance and the Kyoto Protocol: Building a Backbone into a 'Flexible' Regime," Yearbook of International Environmental Law 9 (1999): 48; and Meinhard Doelle, "Compliance and Enforcement in the Climate Change Regime," in Hollo, Kulovesi and Mehling, Climate Change and the Law, op. cit., 165.

22 Montreal Protocol Article 8; and "Non-compliance Procedure" in "Report of the fourth meeting of the Parties to the Montreal Protocol" (25 November 1992) UN Doc UNEP/ OzL.Pro.4/15, Annex IV, as amended by "Report of the tenth meeting of the Parties to the Montreal Protocol” (3 December 1998) un Doc Unep/OzL.Pro.10/9, Annex II, paragraph 7. See also Martti Koskenniemi, "Breach of Treaty or Non-Compliance? Reflections on the Enforcement of the Montreal Protocol," Yearbook of International Environmental Law 3 (1993): 123; and Birnie, Boyle and Redgwell, International Law and the Environment, op. cit., $353-354$.

23 Kyoto Protocol Article 18; and Decision 27/смp.1, Annex, section IV. See CardesaSalzmann, "Constitutionalising Secondary Rules," op. cit., 114; and Doelle, "Compliance and Enforcement," op. cit., 167.

24 As proposed by Switzerland: ENB 9/551, "Summary of the First Meeting of the Intergovernmental Committee for the Nagoya Protocol," 9.

25 This characteristic is also present in other UnECE instruments: Protocol on Pollutant Release and Transfer Registers to the Convention on Access to Information, Public Participation in Decision-Making and Access to Justice in Environmental Matters (Kiev, 21 May 2003, in force 8 October 2009) 2629 unts 119, Article 12 (which makes reference to 'members of the public') and Decision I/2, "Review of Compliance" (20-22 April 2010) Un Doc ECE/MP.PRTR/2010/, paragraph 18; Convention on the Protection and Use of Transboundary Watercourses and International Lakes (Helsinki, 17 March 1992, in force 6 October 1996) 1936 UnTs 269, and Decision VI/1, "Support to implementation 
the compliance committee. Interestingly, however, these innovative characteristics of the Aarhus Compliance Committee are balanced out by the fact that its decisions are subject to consensus approval by the Convention's governing body - thereby implicitly giving a 'veto power' to the Party whose compliance issues are at stake. ${ }^{26}$ With regard to inspiration from other MEAs, a measure of caution has been called for by a commentator, who emphasizes the need for careful scrutiny of whether the characteristics of other compliance mechanisms may be effectively utilized to address ABs-related compliance issues that will likely involve requests for benefit-sharing in the context of commercial relationships. ${ }^{27}$

At the time of writing it remains too early to determine which of these features will be included in the compliance procedures under the Nagoya Protocol. ${ }^{28}$ In the intergovernmental process preparing for the Protocol's entry into force, it has also been noted that international treaties other than MEAs, such as human rights ones, may be taken into account in devising the compliance mechanism for the Protocol..$^{29}$ This may arguably serve to better address Parties' lack of political will to comply with the Protocol, which appears to be addressed more often in the context of human rights bodies than in the context of MEA compliance procedures, which rather tend to focus on capacity issues. Consideration of compliance mechanisms under international human

and compliance" (28-30 November 2012) UNECE Doc ECE/MP.WAT/37/Add.2, Annex II; Protocol on Water and Health to the 1992 Convention on the Protection and Use of Transboundary Watercourses and International Lakes (London, 17 June 1999, in force 4 August 2005) 2331 unts 202 Article 15 and Decision I/2, "Review of compliance" (3 July 2007) Unece Doc ECE/MP.wh/2/Add.3, paragraph 16. See also Svitlana Kravchenko, "The Aarhus Convention and Innovations in Compliance with Multilateral Environmental Agreements," Colorado Journal International Environmental Law and Policy 18 (2007): 1.

26 Veit Koester, "Aarhus Convention/Mop-4: The Compliance Mechanism - Outcomes and a Stocktaking," Environmental Policy and Law 41 (2011): 196, 197-198.

27 Young, “An International Cooperation Perspective," op. cit., 489.

28 ICNP Recommendation 2/7, "Cooperative procedures and institutional mechanisms to promote compliance with the Protocol and to address cases of non-compliance" in ICNP, "Report of the second meeting," UnEP/CBD/COP/11/6, Annex.

29 ICNP Recommendation 1/4 "Cooperative procedures and institutional mechanisms to promote compliance with the Protocol and to address cases of non-compliance," paragraph 1, in ICNP, "Report of the first meeting," UNEP/CBD/ICNP/1/8, Annex, where there is an open-ended reference to 'taking into account the experience and lessons learned from other relevant multilateral agreements.' 
rights treaties may further provide options to factor in the specificities of the Nagoya Protocol with regard to indigenous and local communities. ${ }^{30}$

\section{Distinctive Features}

The unique obligations arising from the Protocol may lead Parties to explore innovative approaches to multilateral compliance procedures and mechanisms. There are at least three aspects that may make the Protocol compliance mechanism quite distinctive from those under other MEAs:

a) the interaction between the bilateral obligations arising in the context of a specific relation between a provider and user country, on the one hand, and erga omnes partes obligations contained in the Protocol;31

b) compliance with the international obligations of State Parties vis-à-vis indigenous and local communities;

c) compliance involving relations between States and private entities.

These will be discussed in turn below. It should also be noted in passing that other elements under the Nagoya Protocol may require distinctive solutions. This is the case of ensuring balanced representation among provider and user countries in a future compliance committee; addressing issues of confidentiality; ${ }^{32}$ and taking into account the specific needs of developing countries. $^{33}$

30 ENB 9/551, "Summary of the First Meeting of the Intergovernmental Committee for the Nagoya Protocol," 10; and Morgera, "First Meeting of the Intergovernmental Committee for the Nagoya Protocol,” op. cit., 190.

31 Note that this feature may not be unique to the Nagoya Protocol: it appears to distinguish also other 'collective regimes' that relate to resources that are to a great extent under State jurisdiction such as the United Nations Convention to Combat Desertification and the ITPGRFA as MEAs that at the same time include generalized obligations for the 'protection of components of global ecosystems', thus enhancing 'the application of principles and duties of general international law' as well as bilateral and reciprocal international obligations as part of the economic instruments for their application: Cardesa-Salzmann, "Constitutionalising Secondary Rules," op. cit., 109.

32 See this commentary on Article 14, section 5.

33 See this commentary on Articles 22-23 and 25. 


\subsection{Compliance in Bilateral Relations between Provider and User Countries}

Currently, there is no existing compliance mechanism under an MEA to address State compliance with obligations to ensure that users under its jurisdiction respect other countries' national legislation. ${ }^{34}$ In addition, intergovernmental discussions preparing for the entry into force of the Protocol initially highlighted an underlying divergence of views among СвD parties in this regard, namely whether the Protocol's compliance mechanisms will address Parties' compliance with their obligations related to users' compliance with domestic ABS frameworks related to genetic resources ${ }^{35}$ and traditional knowledge, ${ }^{36}$ and with MAT. ${ }^{37}$ As already discussed, ${ }^{38}$ unusually, the Protocol refers to 'compliance' not only in the traditional sense under international environmental law of State Parties' compliance with their international obligations, but also in the case of individual users' compliance with applicable laws and MAT at the national level - where users will most likely be private individuals or entities. ${ }^{39}$ This has led certain developed countries to argue that Protocol Articles 15-16 and 18 were excluded from the purview of a future compliance mechanism, as these articles fundamentally relate to users' compliance. The свD Secretariat explicitly clarified that State Parties to the Protocol are bound by international law to comply with all their obligations under the Protocol, including the international obligations concerning individual users' compliance contained in Protocol Articles 15-16 and 18, compliance with which could all be reviewed under the Protocol's compliance mechanism to be established. ${ }^{40}$

34 A comparison could nonetheless be drawn with the compliance procedures under CITES: we are grateful to Tomme Young for drawing our attention to this point. For instance, the Management Authority of Japan is required to reconfirm directly to the Management Authority of the country of export, prior to the authorization of the import of the specimen, which export is prohibited under the law of that exporting country: Isozaki, "Enforcement of ABs Agreements," op. cit., 440.

35 See this commentary on Article 15.

36 See this commentary on Article 16.

37 See this commentary on Article 18.

38 See this commentary on Article 15, section 2.

39 See EN в 9/551, "Summary of the First Meeting of the Intergovernmental Committee for the Nagoya Protocol," 12.

40 ICNP Recommendation $1 / 4$, preambular recital (emphasis added). See also Egypt's statements on behalf of the African Group on this matter in ICNP, "Report of the first meeting," paragraph 151 . Note also the statement made by the ICNP Co-Chair Casas during the meeting that 'Parties to the Protocol are bound by international law to comply with all 
These international obligations clearly relate both to domestic law-making action (or the enactment of other domestic - policy and administrative - measures) and international cooperation in transnational enforcement efforts. The latter seemed to be particularly important for provider countries, who may be able to use (or at least threaten to use) a Party-to-Party trigger under a future compliance mechanism to ensure that user countries cooperate in ensuring access to justice in cases of misappropriation.

Against this background, it can be expected that typical non-compliance instances that may be brought to the attention of a future compliance committee under the Protocol may include a Party claiming that another Party has failed to take domestic measures required for the implementation of the Protocol, thereby preventing persons or entities in the claiming Party from obtaining access or receiving benefits; or one Party alleging a breach of an inter-State ABS arrangement concluded with another Party. ${ }^{41}$ Other claims may also involve lack of international cooperation in addressing users' alleged violations of domestic ABs frameworks. ${ }^{42}$

Due to the importance of compatible provider and user countries' legislative activities on ABS for the full operationalization of the Protocol, ${ }^{43}$ it may also be suggested that the compliance mechanisms and procedures will be heavily involved in the advice and assessment of national ABs laws. To that extent, a comparison with the CiTes compliance processes and the cites National Legislation Project may be useful. ${ }^{44}$ The Project was established in 1992 in

their obligations under the Protocol, and that these obligations include compliance with domestic legislation, as contained in Protocol Articles 15-16, as well as compliance with MAT, as contained in Protocol Article 18; and if a Party does not take these compliancerelated measures, this is considered non-compliance under the Protocol and will be reviewed under the compliance mechanism to be established:' EN B 9/551, "Summary of the First Meeting of the Intergovernmental Committee for the Nagoya Protocol," 8.

41 Young, "An International Cooperation Perspective," op. cit., 488. In the latter case, however, it could be possible for a bilateral ABs treaty to be in place, which may provide for dispute-settlement mechanisms: we are grateful to Tomme Young for drawing our attention to this point. On bilateral ABs treaties, see this commentary on Article 4, section 3.

42 Nagoya Protocol Article 15(3). See this commentary on Article 15.

43 See this commentary on Articles 4-5 and comments on the need for 'inter-operability' between domestic ABs frameworks in Young, "An International Cooperation Perspective," op. cit., 488.

44 Cites Resolution Conf. 8.4 (Rev. cop15) "National Laws for implementation of the Convention," CITES, accessed 30 November 2013, <www.cites.org/eng/res/08/08-04R15. php $>$. For a comparative discussion, see generally Morgera et al., "Implementation Challenges and Compliance in MEA Negotiations," op. cit. 
the absence of an explicit basis in the Convention. The cites Secretariat is enabled to determine whether Parties' national legislation adequately implements the Convention, by categorizing each country's legislation as meeting all, some, or none of the requirements for implementing CITES. The categorization is based on a clear articulation of the minimum requirements set by CITES in terms of implementing the convention in national law. Countries in the lower category have to develop a 'legislation plan' establishing agreed steps and a timeframe for the adoption of national legislation. Failing to submit the Plan or to adopt adequate legislation by set deadlines may result in the recommended suspension of commercial trade in all cites species with the Party, although the Secretariat may withhold action if good legislative progress has been made by a Party. ${ }^{45}$ The system rests on the longstanding practice of the Standing Committee, which may recommend trade sanctions (suspension of wildlife trade) in cases where a country has not met its legislative obligations. In the framework of this multilateral process, national legislative sovereignty is closely monitored and significantly influenced by CiTEs bodies, on the basis of a comparative analysis of existing national laws and international guidelines, and a network of experts participating in relevant multilateral deliberations and field activities. ${ }^{46}$ This approach, however, would require a 'cultural shift' among Parties to the CBD, which have hitherto expressed opposition to any international monitoring or assessment of national legislation. ${ }^{47}$

\subsection{Compliance vis-à-vis Indigenous and Local Communities}

The Nagoya Protocol provisions on traditional knowledge and genetic resources held by indigenous and local communities ${ }^{48}$ significantly contribute to making States' role 'functional' to the protection of the interests of these

45 Cites Resolution Conf. 8.4 which instructs the Standing Committee to determine which Parties have not adopted appropriate measures for effective implementation of the Convention and to consider appropriate compliance measures, which may include recommendations to suspend trade, in accordance with CITES Resolution Conf. 14.3; directs the Secretariat to seek external funding to enable it to provide technical assistance to Parties in the development of their measures to implement the Convention; and invites all Parties, governmental, intergovernmental, and non-governmental organisations, and other sources to provide financial and/or technical assistance for the development and effective implementation of such measures; and cITES ArticleXII. The authors are grateful to Soledad Aguilar for her contributions on Cites in Morgera et al., "Implementation Challenges," op. cit.

46 Morgera, "Bilateralism at the Service of Community Interests?," op. cit., 756.

47 Morgera and Tsioumani, "Yesterday, Today, and Tomorrow," op. cit., 7.

48 See this commentary on Articles 5-7. 
communities located in their territories, as well as of these communities in other States. ${ }^{49}$ It remains to be seen how compliance with the Protocol's obligations related to indigenous and local communities will be monitored, particularly as currently, there is no existing mechanism under an MEA to address State compliance with obligations towards its indigenous and local communities. In addition or in alternative, a future compliance committee under the Protocol may have to assess compliance with, or at least consider the role of, indigenous and local communities' laws, protocols and procedure ${ }^{50}$ in ensuring compliance with the obligations of Parties vis-à-vis these communities. To some extent this task may be facilitated by the use of community protocols, ${ }^{51}$ which may distil the relevant views, laws and procedures of these communities in relation to ABS. In that connection, States' functional role may likely extend to support also the implementation and ensure the respect of community protocols, giving them legal effect in national legal system with a view to ensuring compliance by users and collaboration with user countries in that endeavor. $^{52}$

Intergovernmental negotiations preparing for the Protocol's entry into force provide some indications of the options that may be considered if Parties agree to adequately gear multilateral mechanisms and procedures to deal with compliance with the indigenous and local community-related obligations of Parties. One obvious possibility is that of triggering the compliance procedure with a submission from 'a member of the public' or more specifically by 'indigenous and local communities,' which has been discussed together with the proposal of conditioning such trigger to the 'support of the Party in whose territories the community is located.' 53 This seems to demonstrate that while CBD

49 This argument was first put forward in Morgera, "Bilateralism at the Service of Community Interests?," op. cit., 745 and inspired by Ellen Hey, "Global Environmental Law and Global Institutions: A System Lacking 'Good Process,'” in Cosmopolitanism in Context: Perspectives from International Law and Political Theory, ed. Roland Pierik and Wouter Werner (Cambridge: Cambridge University Press, 2010), 45.

5o Nagoya Protocol Article 12(1). See this commentary on Article 12, section 2.

$51 \quad$ Nagoya Protocol Articles 12 and 21. See previous discussions on community protocols in the context of this commentary on Article 12, section 2.1; as well as Jonas, Bavikatte and Shrumm, "Community Protocols and Access and Benefit-Sharing," op. cit., 68; and Munyi and Jonas, "Implementing the Nagoya Protocol," op. cit., 238-244.

$5^{2}$ Morgera, "Bilateralism at the Service of Community Interests?," op. cit., 762.

53 ICNP Recommendation $2 / 7$, section D, paragraph (1)(d). The text appears in square brackets in the draft decision. It is noteworthy that an expert group on compliance that met earlier in 2012 had noted the possibility that a community trigger under the Protocol compliance mechanism be accompanied by a 'number of qualifiers or conditions': ICNP, 
Parties display some openness to consider a stakeholder or community trigger, a significant degree of caution in that regard remains. It should also be noted that a trigger by any member of the public (rather than indigenous and local communities) would provide private-sector users and providers with access to the Protocol's compliance mechanism, as well as environmental NGOs and other ABS stakeholders. Other options include the possibility for indigenous and local communities to submit information directly to a future compliance committee, which, combined with the possibility for the compliance committee to self-trigger, could provide an alternative to a community trigger. Another possibility is to allow representatives of indigenous and local communities to participate in a future compliance committee as members or as observers, and/or for the committee to directly consult with relevant communities in the course of its consideration of cases of non-compliance. ${ }^{54}$

An innovative idea that emerged during the Protocol negotiations, but that did not make it in the agreed text, was to establish an international ombudsperson to support developing countries and indigenous and local communities in identifying breaches of rights and to provide independent technical and legal support in ensuring the effective redress of such breaches. ${ }^{55}$ If established, such an innovative feature in the MEA landscape ${ }^{56}$ would essentially constitute an international institution able to work on the ground directly with indigenous and local communities, while enabling these communities to have immediate access to an international avenue to address alleged disrespect of their rights protected under the Protocol. ${ }^{57}$ While the final text of the Protocol does not make reference to an international ombudsperson, there is nothing

"Report of the Expert Meeting on Cooperative Procedures," UneP/CBD/ICNP/2/12, fns. 21-22.

54 ICNP Recommendation 2/7, Annex. See Morgera, "Second meeting of the ICNP," op. cit., 244.

55 See Montreal I Draft, draft article 14 bis. ENB 9/527, "Summary of the Resumed Ninth Meeting of the Working Group on ABs," 11 and 15.

56 In the human rights context, an ombudsman is a national institution that contributes to the enjoyment and protection of human rights. In particular, 'the traditional model of an ombudsman has been an independent institution that is established by and answerable to parliament, with the power to consider complaints and conduct investigations on its own initiative, and to make recommendations to government rather than to adopt biding decisions. (...) there are two main models of ombudsman (though some ombudsmen are hybrid between the two): the classical ombudsman and the human rights ombudsman:' see Andrew Byrnes and Catherine Renshaw, "Within the State," in Moeckli, Shah and Sivakumaran, International Human Rights Law, op. cit., 498, 514-5.

Morgera and Tsioumani, "Yesterday, Today, and Tomorrow," op. cit., 20. 
to prevent Parties from establishing such a body in the future through a decision by the Protocol's governing body. ${ }^{58}$ And indeed the intergovernmental discussions preparing for the Protocol's entry into force have witnessed the resurfacing of this idea. The Intergovernmental Committee for the Nagoya Protocol is thus considering at the time of writing whether an international ombudsman office could provide an intermediate layer in the multilateral compliance mechanisms and procedures where the Party concerned and its relevant communities could initially address implementation challenges with some international facilitation, but without the immediate involvement of a future compliance committee. ${ }^{59}$ The ombudsman could thus function as a mediator between governments and indigenous and local communities, and a filter to select well-founded community submissions for transmission to a future compliance committee. ${ }^{60} \mathrm{~A}$ comparable institution can be found in the context of the World Bank family: the Compliance Advisor/Ombudsman (CAO) of the International Finance Corporation (IFC). ${ }^{61}$ The CAO is an independent oversight authority that receives and addresses complaints from any person, group or community affected, or likely to be affected, by IFC-financed projects, and then reports directly to the President of the World Bank Group. ${ }^{62}$ The Ombudsman's modus operandi includes field visits to the site of contested projects and interviews with all parties involved: staff of the private company,

$5^{8} \quad$ Article 26(4)(a): see this commentary on Article 26, section 2.

59 ICNP Recommendation 2/7, Annex, F bis, which reads: '[The Committee shall establish the office of an ABS ombudsman to provide assistance to developing countries and indigenous and local communities to identify instances of non-compliance and make submissions to the Committee.]' (brackets in the original). See also En B 9/579, "Summary of the Second Meeting of the Intergovernmental Committee for the Nagoya Protocol," 12.

60 Morgera, "Second Meeting of the Intergovernmental Committee for the Nagoya Protocol," op. cit., 245.

61 See "Compliance Advisor/Ombudsman" (CAO), CAO, accessed 30 November 2013, <www. cao-ombudsman.org/>. The International Finance Corporation (IFC) is the 'private arm' of the World Bank: it provides financing to private operators active in developing countries: IFC Articles of Agreement (as amended through 27 June 2012), accessed 30 November 2013, <www.ifc.org/wps/wcm/connect/1c95b500484cb68d9f3dbf5f4fc3 fl8b/IFC_Articles_of_Agreement.pdf?MOD=AJPERES $>$, Article 1. For a discussion, see Elisa Morgera, "Human Rights Dimensions of Corporate Environmental Accountability," in Human Rights in International Investment Law and Arbitration, ed. Pierre-Marie Dupuy, Francesco Francioni and Ernst-Ulrich Petersmann (Oxford: Oxford University Press, 2009), 511.

62 CAO Terms of Reference, Operational Guidance and Operational Practice in "CAO Operational Guidelines," CAO, accessed 30 November 2013, <www.cao-ombudsman.org/ howwework/documents/CAOOperationalGuidelines2013_ENGLISH.pdf>. 
local authorities, affected communities representatives, other relevant local organizations and IFC staff. Complaints, reports of field missions and recommendations are all published on the CAO website, together with updates on ongoing investigations. ${ }^{63} \mathrm{~A}$ similar body under the Nagoya Protocol, taking into consideration the specificities of ABS transactions, in particular regarding the central role of domestic ABS frameworks, ${ }^{64}$ could possibly address many concerns related to compliance on the ground, and facilitate relations between relevant ABS stakeholders.

It should also be added that in relation to the indigenous and local community-related provisions of the Protocol, international human rights monitoring bodies may become involved in scrutinizing whether national-level implementation of the Nagoya Protocol complies with applicable international human rights instruments. ${ }^{65}$ To the extent that these other fora would work in a mutually supportive manner with the Protocol and its compliance mechanisms and procedures, this may provide an opportunity for cross-compliance. ${ }^{66}$

\subsection{Compliance in State-Private Parties Relations}

Parties will also need to discuss whether, to what extent and how the Protocol's compliance mechanisms and procedures may address questions related to compliance in relationships between a State and private parties. If a stakeholder trigger were to be created for the ABs compliance procedures, private users or providers such as a biotech multinational or a research centre could potentially bring claims before a future compliance mechanism for failures by Parties to create clear, predictable and effective domestic ABs frameworks.

Furthermore, it cannot be excluded that certain ABS arrangements, particularly in the context of bilateral or regional agreements, may be considered a form of 'foreign direct investment' 67 (given the extensive interpretation of this term under international investment law ${ }^{68}$ and its protection also under human rights instruments). ${ }^{69}$ As a result Protocol Parties could possibly find

63 "Cases," CAO, accessed 30 November 2013, <www.cao-ombudsman.org/cases/>.

64 See this commentary on Article 16, section 2.

65 Savaresi, "International Human Rights Law Implications," op. cit., 79.

66 Morgera, Buck and Tsioumani, “Conclusions," op. cit., 509.

67 See this commentary on Article 4, section 2.1.

68 Jan Wouters, Nicolas Hachez and Sanderijn Duquet, "International Investment Law: The Perpetual Search for Consensus," in Foreign Direct Investment and Human Development: The Law and Economics of International Investment Agreements, ed. Olivier de Schutter, Johan F.M. Swinnen and Jan Wouters (New York: Routledge, 2013), 25.

69 See for example Nicolas Klein, "Human Rights and International Investment Law: Investment Protection as Human Right," Goettingen Journal of International Law 4 (2012): 
themselves brought before investment dispute settlement mechanisms by private $\mathrm{ABS}$ users,$^{70}$ where human rights standards may be invoked by investors to challenge States' fulfillment of their obligation to provide adequate access to justice to non-State parties. ${ }^{71}$ Such actions could arguably lead to differing interpretations of Protocol provisions by a future compliance committee under the Protocol on the one hand, and investment dispute bodies on the other hand, as the latter may have to balance the Protocol's objective with those of international investment law. ${ }^{72}$

The Protocol's compliance mechanism will interact with other international processes established under the Protocol. It will supplement the review of implementation by the Protocol's governing body, ${ }^{73}$ which specifically includes review of the effectiveness of the Protocol's provisions on compliance with MAT. ${ }^{74}$ A future compliance committee under the Protocol may also be allowed to take into account (upon request or of its own initiative) the reports submitted by Parties on their implementation of the Protocol. ${ }^{75}$

Potentially significant linkages may be established (or clarified) between the role of the compliance mechanisms and procedures, and the operation of the ABs Clearinghouse. ${ }^{76}$ Parties will have to input information on their

179; Luke E. Peterson, Human Rights and Bilateral Investment Treaties. Mapping the Role of Human Rights Law within Investor-State Arbitration (Montreal: Rights \& Democracy, 2009); and Bruno Simma, "Foreign Investment Arbitration: A Place for Human Rights," International and Comparative Law Quarterly 60 (2011): 573.

70 This may be particularly the case of ABs arrangements that provide benefit-sharing through the establishment of research facilities in the provider country: see this commentary on Article 5. We are grateful to Lorenzo Cotula for a useful exchange of ideas in this regard.

71 Savaresi, "International Human Rights Law Implications," op. cit., 72.

72 See for example Jorge E. Viñuales, "Foreign Investment and the Environment in International Law: An Ambiguous Relationship," British Yearbook of International Law 80 (2010): 244 .

73 See this commentary on Articles 26 and 31. For a similar question under the Biosafety Protocol, see Mackenzie et al., Explanatory Guide to the Cartagena Protocol, op. cit., 193-196.

74 Nagoya Protocol Article 18(4). See Greiber et al., Explanatory Guide, op. cit., 243 and this commentary on Article 18.

75 See this commentary on Article 29.

${ }_{7} 6$ See this commentary on Article 14, section 4. 
national implementation measures (such as on domestic ABs frameworks) in the ABS Clearinghouse, and failure to do so may be considered a case of noncompliance. Once the information is in the system, Parties may use the ABS Clearinghouse to monitor compliance by other Parties or perhaps even use that information as a defense against allegation of non-compliance against them. Crucially, once included in the ABs Clearinghouse, national permits will be elevated to internationally recognized certificates of compliance, which hold an important role in documenting users' compliance with the bilateral ABS system set up by the Protocol. ${ }^{77}$

\section{5}

\section{Dispute Settlement}

Article 30 requires that the compliance procedures and mechanisms be 'separate from, and without prejudice to' dispute settlement procedures. In accordance with the Convention, Parties to the Protocol are required to address any dispute among them first of all by seeking solution by negotiation, ${ }^{78}$ and, failing that, by jointly seeking the good offices of, or request mediation by, a third party ${ }^{79}$ Furthermore, when ratifying the Nagoya Protocol, a State may declare in writing that for a dispute that cannot be resolved through negotiation or mediation, the State may initiate an arbitration procedure and/or submit the dispute to the International Court of Justice. ${ }^{80}$ If the Parties to the dispute have not accepted the same or any procedure, the dispute will be submitted to conciliation, unless the Parties agree otherwise. ${ }^{81}$

It should be finally noted that the Protocol's compliance procedures and mechanisms might be used as an alternative to, or concurrently with, a dispute settlement procedure. Parties may bring their concerns to the attention of a future compliance committee before resorting to international dispute settlement mechanisms in accordance with the СвD. In that case, the compliance mechanism might help prevent disputes and thus minimize the need for dispute settlement, which in all events is an extremely unlikely option in

77 Nagoya Protocol Article 17(2) and (3): see this commentary on Article 17, section 3. See Morgera, "First Meeting of the Intergovernmental Committee for the Nagoya Protocol," op. cit., 190.

78 CBD Article 27(1).

79 CBD Article 27(2).

8о СвD Article 27(3).

81 свD Article 27(4). See Greiber et al., Explanatory Guide, op. cit., 249. 
international environmental law. ${ }^{82}$ On the other hand, it cannot be excluded that the same compliance issue may be considered at the same time by the Protocol's compliance mechanism and by an international dispute resolution mechanism. In that case, it has been emphasized that the relationship between compliance mechanisms under MEAs and general international law's enforcement mechanisms is still undefined. ${ }^{83}$ Some commentators, however, have argued that the final decision of an international judicial organ would have to be considered 'res iudicata' by compliance committees. The latter could rather contribute through their own procedures to support the enforcement of the international court's ruling. ${ }^{84}$

82 For similar reflections in the context of the Biosafety Protocol, see Mackenzie et al., Explanatory Guide to the Cartagena Protocol, op. cit., 196. Recent practice under other MEAs also seems to indicate that Parties prefer to handle bilateral-type non-compliance instances through negotiations rather than through compliance mechanisms or formal dispute settlement procedures: Cardesa-Salzmann, "Constitutionalising Secondary Rules," op. cit., 126-128.

$83 \quad$ Klabbers, "Compliance Procedures," op. cit., 1005-1007.

84 Tullio Treves, "The Settlement of Disputes and Non-Compliance Procedures," in Treves et al., Non-Compliance Procedures, op. cit., 499. 